\title{
Induksi Akar Rambut Gandarusa (Justicia gendarussa Burm. f.) dengan Perlakuan Perbedaan Lama Waktu Infeksi Agrobacterium rhizogenes strain YM072001 dan A4T
}

(The Induction of Gandarusa (Justicia gendarussa Burm. f.) Hairy Root under Different Infection Period of Agrobacterium rhizogenes strain YM072001 dan A4T)

\author{
Dwi Kusuma Wahyuni(1), Qonitatun Nisa' ${ }^{1}$, Hery Purnobasuki1), Tri Muji Ermayanti2), \\ Bambang Prajoga ${ }^{3)}$ dan Edy Setiti Wida Utami') \\ 1) Departmen Biologi, Fakultas Sains dan Teknologi, Universitas Airlangga \\ 2) Pusat Penelitian Bioteknologi LIPI \\ 3) Fakultas Farmasi, Universitas Airlangga \\ *Email korespondensi: kusumaanwar@yahoo.com
}

Diterima 23 Januari 2015, diterima untuk dipublikasikan 7 Agustus 2015

\begin{abstract}
Abstrak
Penelitian ini bertujuan untuk menginduksi akar rambut eksplan daun Gandarusa (Justicia gendarussa Burm.f.) dengan perlakuan perbedaan lama waktu infeksi Agrobacterium rhizogenes strain YM072001 dan A4T dan mengevaluasi lama waktu infeksi terbaik untuk induksi akar rambut. Eksplan daun diinokulasi di media MS (Murashige dan Skoog) cair yang berisi bakteri Agrobacterium rhizogenes dengan $O D_{600}=0,1$ selama 10, 20, 30, 40, 50, dan 60 menit. Kokultivasi di MS padat selama 2 hari, lalu disubkultur ke media MS padat. Data dianalisis secara deskriptif. Akar rambut mulai tumbuh pada minggu ketiga. Induksi akar rambut berhasil pada eksplan dengan perlakuan strain YMB072001 dengan lama waktu infeksi 20, 40, dan 50 menit. Strain A4T juga berhasil menginduksi eksplan membentuk akar rambut dengan perlakuan 10 menit. Lama waktu infeksi terbaik untuk strain YMB072001 adalah 20 menit dan untuk strain A4T adalah 10 menit.

Kata kunci: Agrobacterium rhizogenes, akar rambut, Justicia gendarussa Burm. f., waktu infeksi
\end{abstract}

\begin{abstract}
The objective of this study were to induce hairy root of Gandarusa leaf explants by differences of Agrobacterium rhizogenes infection time treatment and to evaluate the best infection time for induction. Leaf explants were inoculated on MS (Murashige dan Skoog) liquid medium with bacterial concentrations of $O D_{600}=0,1$ for 10, 20, 30, 40, 50, and 60 minutes and 2 days co-cultivated on MSO solid medium then sub cultured on MSO solid medium. Data were analyzed descriptively. Hairy roots were growing on the third week. Explants were successfully induced by strain YMB 072001 at 20, 40, and 50 minutes treatment. A4T strain was successfully induced by 10 minute of treatment. The best infection time for hairy root induction in gandarusa leaf explants for YMB 072001 strains was 20 minutes and for A4T strain was 10 minutes.
\end{abstract}

Keywords: Agrobacterium rhizogenes, hairy root, infection time, Justicia gendarussa Burm. $f$. 


\section{PENDAHULUAN}

Tanaman obat Indonesia sangat beragam. Salah satu tanaman obat yang banyak dimanfaatkan adalah gandarusa (Justicia gendarussa Burm. f.). Tanaman gandarusa mengandung alkaloid, triterpenoid, tanin, justicin, steroid, dan gendarusin A dan B. Gendarusin A dan $B$ merupakan senyawa aktif untuk antifertilitas pada pria (Prajogo et al. 2007).

Pemanfaatan gandarusa
secara besar-besaran dihadapkan pada masalah ketersediaannya di alam, karena tanaman ini tumbuh liar dan belum dibudidayakan. Budidaya tanaman secara konvensional membutuhkan waktu yang relatif lama, kadar dan kualitas senyawa aktif yang diinginkan tidak sesuai harapan sehingga diperlukan peran bioteknologi untuk mengatasi hal ini.

Metode produksi senyawa aktif melalui teknik kultur jaringan dipandang lebih efisien jika dibandingkan dengan cara konvensional. Bahan yang diperoleh dengan teknik kultur jaringan dalam keadaan seragam sehingga tidak ada masalah dalam standarisasi. Dengan teknik kultur jaringan juga dapat dilakukan perekayasaan sehingga diperoleh senyawa aktif dengan kualitas yang lebih baik dibandingkan dengan cara konvensional (Syamkumar et al. 2007). Salah satu teknik kultur jaringan untuk produksi metabolit sekunder adalah kultur akar rambut (Hairy Root Culture).

Kultur akar rambut adalah induksi pembentukan struktur akar rambut dengan menginfeksikan Agrobacterium rhizogenes pada tanaman yang akan dikultur. Agrobacterium mempunyai kemampuan untuk mentransfer sebagian bahan DNAnya pada sel tanaman melalui pelukaan. DNA yang ditransfer disebut dengan T-DNA merupakan potongan beberapa ratus kilo basa dari plasmid yang dikenal dengan $\mathrm{Ri}$ plasmid (root inducing plasmid) (Nilsson dan Olsson 1997). Kelebihan teknik kultur akar rambut dibandingkan dengan teknik yang lain adalah senyawa yang dihasilkan lebih stabil karena akar yang diperoleh mempunyai genetik yang stabil, tumbuh cepat dan mudah perwatannya (Rahimi et al. 2008).

Pemanfaatan kultur akar rambut untuk menghasilkan senyawa metabolit sekunder telah banyak dilakukan, antara lain untu produksi lobelin dari Lobelia inflanta L. (Yonemitsu et al. 1990), katarantin dan ajmalin dari Catharanthus roseus G. Don. (Vazquez-Flota et al. 1994), saponin dari Solanum aculeatissum (Ikenaga et al. 1995) glukotropaeolin dari Tripaeolum majus (Wielanek dan Urbanek 1999), asam rosmarin dari Agastache rugosa Kuntze (Lee et al. 2008), dan saponin dari Talinum paniculatum Gaertn. (Manuhara et al. 2012). Sejauh ini penelitian tentang kultur akar rambut (hairy root) untuk memproduksi metabolit sekunder pada tanaman Gandarusa (Justicia gendarussa Burm. f.) belum dilaporkan.

Suatu studi awal perlu dilakukan untuk untuk induksi akar rambut tanaman gandarusa, mengingat banyak faktor yang menentukan keberhasilan kultur akar rambut, antara lain genotip dan kondisi eksplan, ada tidaknya pelukaan, kerapatan bakteri, strain bakteri, lama infeksi dan media (Pardal et al. 2004). Lama infeksi sangat bervariasi tergantung jenis eksplan. Tanaman tomat dibutuhkan waktu 5 menit (Purnamaningsih 2010), tanaman ginsen jawa membutuhkan 
waktu 20 menit (Wahyuningtyas 2011), Agastache rugosa Kuntze membutuhkan waktu 10 menit (Lee et al. 2008), Valeriana sisymbriifolium membutuhkan waktu 20 menit (Rahimi, et al. 2008) dan Withania somnifera L. dan Solanum surttense Burm f. membutuhkan waktu 5 menit (Pawar dan Maheswari 2003). Oleh karena itu penelitian ini bertujuan untuk menginduksi akar rambut dengan perlakuan lama waktu infeksi Agrobacterium rhizogenes strain YM072100 dan strain A4T.

\section{METODE} Bahan

Bahan yang digunakan adalah daun tanaman gandarusa (Justicia gendarussa Burm.f.) yang diperoleh dari Balai Materia Medika Batu Malang. Kultur bakteri Agrobacterium rhizogenes strain YMB072001 dan A4T yang diperoleh dari Pusat Penelitian Bioteknologi Lembaga IImu Pengetahuan Indonesia (LIPI) Bogor. Bahan lain yang digunakan adalah media Murashige and Skoog (MS) padat, Media MS cair (Murashige dan Skoog 1962) antibiotik cefotaxime, nystatin, alkohol 70\%, chlorox (Bayclin), aquadest, fungisida cair (Topsin 500).

\section{Induksi dan pembentukan akar rambut pada eksplan daun}

Daun gandarusa dicuci dengan

sabun cair selama \pm 10 menit, kemudian dibilas dengan air mengalir. Setelah itu direndam dengan larutan fungisida (10 mL/500 mL air) selama kurang lebih 10 menit. Daun dibilas hingga bersih di bawah air mengalir. Di dalam ruang LAF eksplan direndam dalam larutan chlorox $50 \%$ selama 7 menit, selanjutnya dibilas dengan aquadest steril sebanyak 3 kali dan ditiriskan di atas cawan petri yang telah dialasi kertas saring steril.
Kultur $A$. rhizogenes dalam media YMB yang telah berumur 24 jam disiapkan. Pembuatan media transformasi dilakukan dengan cara memasukkan $10 \mathrm{~mL}$ suspensi bakteri dengan $\mathrm{OD}_{600}=0,1 \mathrm{ke}$ dalam $15 \mathrm{~mL}$ erlenmeyer yang telah berisi $15 \mathrm{~mL}$ MS cair. Eksplan daun yang telah dipotong-potong dimasukkan dalam erlenmeyer yang telah berisi media transformasi. Proses infeksi dilakukan dengan menggoyang-goyangkan sesuai dengan waktu perlakuan yaitu 10, 20, 30, 40, 50, dan 60 menit. Kontrol berupa daun tanpa dilakukan infeksi bakteri. Tiap perlakuan diulang 5 kali, dan tiap ulangan terdiri dari 1 eksplan.

Eksplan ditiriskan di atas kertas saring steril, kemudian ditanam pada media MSO padat selama 2 hari untuk proses ko-kultivasi. Setelah 2 hari, eksplan dibilas dengan media MS cair yang mengandung $500 \mathrm{mg} / \mathrm{L}$ antibiotik cefotaxime, kemudian ditanam pada media MS padat yang mengandung $500 \mathrm{mg} / \mathrm{L}$ cefotaxime dan $500 \mu \mathrm{L} / \mathrm{L}$ nystatin. Subkultur dilakukan pada media yang sama hingga tidak ada bakteri yang tumbuh. Kultur diinkubasi dalam ruang gelap. Akar rambut mulai tumbuh pada minggu ke-3. Data efisiensi transformasi yang diperoleh meliputi persentase eksplan membentuk akar rambut dan jumlah akar rambut yang terbentuk setelah minggu ke-6 dianalisis secara deskriptif.

\section{HASIL DAN PEMBAHASAN}

Akar rambut terbentuk pada eksplan daun gandarusa ditandai dengan munculnya tonjolan kecil berwarna putih di sekitar area pertulangan daun yang terinfeksi oleh bakteri $A$. rhizogenes. Tonjolan tersebut muncul pada pertulangan daun setelah minggu ke-2. Akar rambut terbentuk paling cepat pada 
hari ke-15 dengan perlakuan lama waktu infeksi 40 menit, sedangkan pada perlakuan 20 dan 50 menit akar terbentuk pada hari ke-17 pada eksplan yang diinfeksi $A$. rhizogenes strain YMB 072001. Akar rambut terbentuk pada hari ke-28 pada eksplan yang diinfeksi $A$. rhizogenes strain A4T dengan perlakuan lama waktu infeksi selama 10 menit (Gambar 1).

Hasil penelitian tersebut seperti dengan penelitian Ermayanti et al. (2009), akar rambut muncul pada daerah pertulangan ekplan daun seperti pada Artemisia cina dan Artemisia annua. Lama waktu induksi akar rambut juga hampir sama dengan Artemisia cina dan Artemisia annua pada minggu ke-2 sampai minggu ke-3. Pada Agastache rugosa Kuntze akar rambut di minggu ke-3 (Lee et al. 2008), calus Catharanthus roseus L. pada hari kesepuluh (Zargar et al. 2010), Talinum paniculatum Gaertn pada minggu ke-2 (Manuhara et al. 2012), dan Ipomoea batatas pada hari ke-8 (Chandran dan Potty 2008).

Efisiensi transformasi eksplan yang membentuk akar rambut. Akar rambut berhasil diinduksi oleh $A$. rhizogenes strain YMB 072001 dengan perlakuan 20 menit sebesar 40\%, serta perlakuan 40 dan 50 menit masing-masing sebesar $20 \%$. Pada eksplan perlakuan 10, 30, 60 menit dan kontrol tidak membentuk akar rambut. Akar rambut juga berhasil diinduksi oleh $A$. rhizogenes strain A4T pada perlakuan 10 menit sebesar $40 \%$, sedangkan pada eksplan perlakuan lainnya tidak membentuk akar rambut (Gambar 2).

Akar rambut yang tumbuh pada tiap eksplan jumlahnya berbedabeda berkisar 1-2 buah akar rambut. Data jumlah akar rambut yang tumbuh pada tiap eksplan disajikan dalam Gambar 3.

Berdasarkan Gambar 3

diketahui bahwa eksplan yang diinfeksi oleh bakteri $A$. rhizogenes strain YMB 072001 pada perlakuan 20 dan 40 menit berhasil membentuk 2 akar rambut pada tiap eksplan, dan 1 akar rambut pada eksplan perlakuan 50 menit. Sedangkan eksplan lainnya yaitu perlakuan 10, 30, dan 60 menit, dan kontrol tidak membentuk akar rambut. Eksplan yang diinfeksi oleh bakteri $A$. rhizogenes strain A4T berhasil membentuk 1 akar rambut pada tiap eksplan perlakuan 10 menit, sedangkan eksplan lainnya yaitu perlakuan 20, 30, 40, 50, 60 menit, dan kontrol tidak membentuk akar rambut.

Tidak semua eksplan yang diinfeksi oleh $A$. rhizogenes mampu membentuk akar rambut, diduga karena perendaman eksplan dalam suspensi bakteri terlalu lama dapat menyebabkan infeksi bakteri terlalu banyak sehingga jaringan tanaman menjadi stres dan tidak dapat tumbuh (Purnamaningsih 2010). Tidak terbentuknya akar rambut pada eksplan juga diduga karena eksplan tidak dapat mengeluarkan senyawa fenolik dalam jumlah yang cukup untuk dapat merangsang bakteri secara kemotaksis agar mudah menempel pada sel tanaman. Gelvin (2000) menyatakan bahwa produksi senyawa fenolik akibat pelukaan tanaman dapat membuat bakteri lebih mudah menempel pada dinding sel tanaman.

Efisiensi transformasi yang relatif rendah diduga karena adanya perbedaan kompetensi eksplan terhadap infeksi Agrobacterium. Ada beberapa faktor yang menentukan kompetensi eksplan, antara lain spesies atau genotip asal eksplan, jenis organ yang digunakan sebagai 


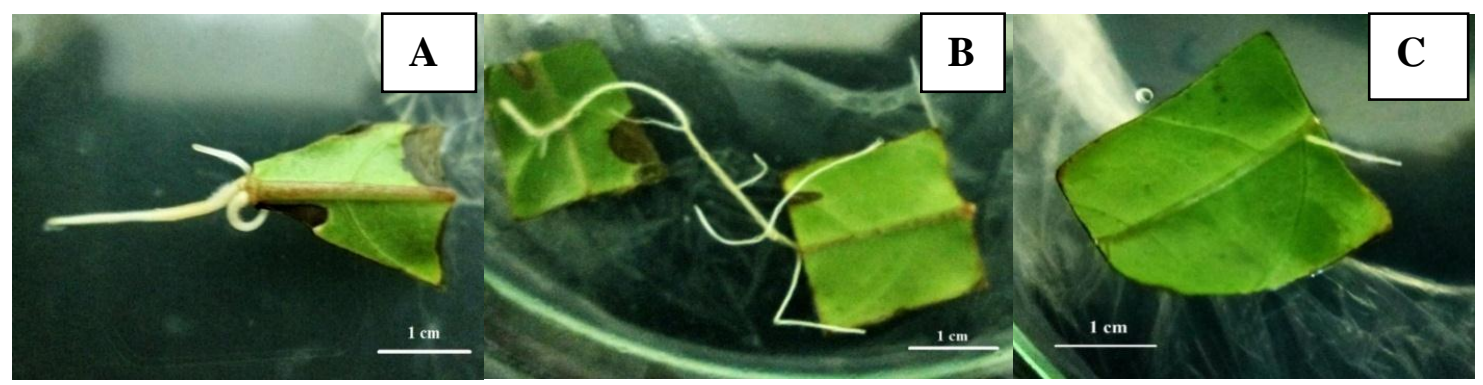

Gambar 1. Eksplan yang membentuk akar rambut yang diinfeksi $A$. rhizogenes strain YMB 072001 selama 40 menit (A), selama 50 menit (B), dan yang diinfeksi $A$. rhizogenes strain A4T selama 10 menit (C).

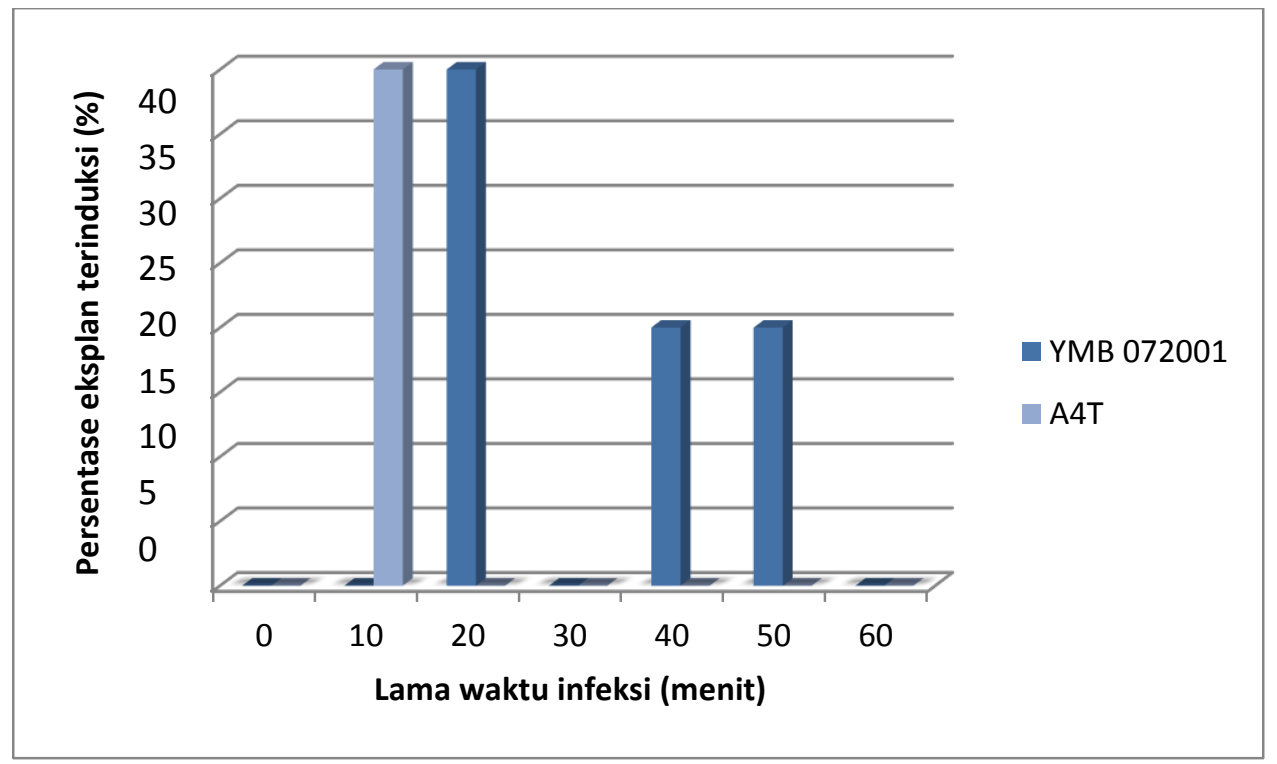

Gambar 2. Grafik persentase eksplan yang membentuk akar rambut dengan berbagai lama waktu infeksi $A$. rhizogenes strain YMB 072001 dan A4T 


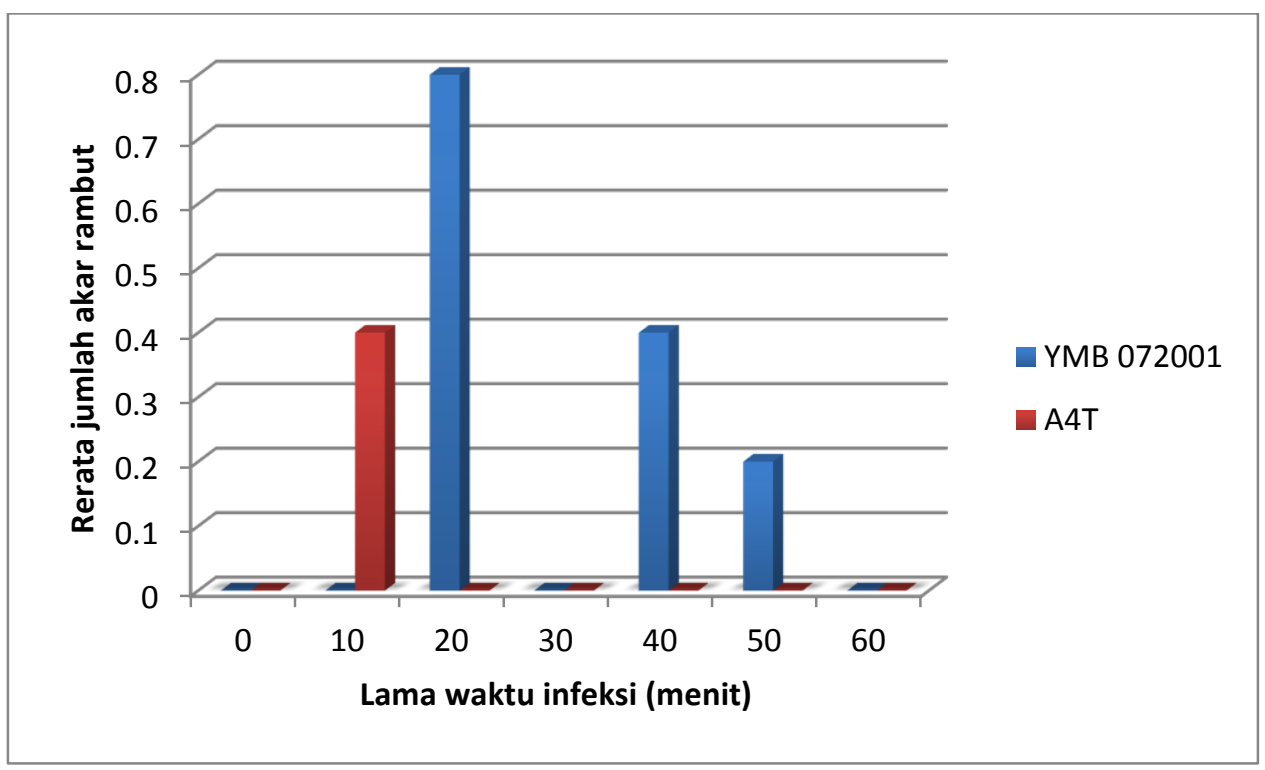

Gambar 3. Grafik rerata jumlah akar rambut yang terbentuk pada eksplan daun gandarusa dengan berbagai lama waktu infeksi $A$. rhizogenes strain YMB 072001 dan A4T

eksplan, tingkat perkembangan organ, bahkan historis dari masing-masing eksplan yang digunakan (ToruanMathius et al. 2004, Toruan-Mathius et al. 2007, Hu dan Du 2006, Ermayanti et al. 2009, Saleh dan Thuc 2009, Chandran dan Potty 2011, Pawar dan Maheswari 2004, Swain et al. 2012) Swain et al. (2012) menunjukkan bahwa penggunaan internodus Clitoria ternatea lebih rentan inokulasi Agrobacterium dibandingkan dengan daun. Eksplan yang diambil dari ruang terbuka jauh lebih resposnsi terhadap inokulasi dibanding eksplan yang diambil dari tanaman in vitro.

Owen dan Smigocki (1988) menjelaskan bahwa kemampuan infeksi Agrobacterium terhadap tanaman berbeda-beda dalam efektivitas transfer T-DNA, disebabkan karena adanya hubungan antara virulensi isolat Agrobacterium yang dipakai dan kerentanan kultivar tanaman. Tiap spesies tanaman atau bahkan kultivar tanaman dalam spesies yang sama mempunyai tingkat kerentanan terhadap Agrobacterium yang berbeda-beda. Perbedaan jumlah eksplan yang terinduksi dan jumlah akar rambut yang terbentuk pada penelitian ini diduga akibat perbedaan virulensi isolat Agrobacterium rhizogenes yang digunakan dan kerentanan kultivar tanaman. Ermayanti et al. (2009) menggunakan 10 strain yang berbeda menghasilkan prosentase tranformasi yang berbeda.

\section{KESIMPULAN}

Akar rambut berhasil diinduksi dari daun Gandarusa (Justicia gandarussa Burm.f.) dengan menggunakan perbedaan lama waktu infeksi Agrobacterium rhizogenes strain YM072001 dan A4T. Lama waktu infeksi yang terbaik adalah 20 menit untuk strain YM072001 dan 10 menit untuk strain A4T. 


\section{DAFTAR PUSTAKA}

Chandran RP, Potty VP (2008) Induction of hairy roots through the mediation of four strains of Agrobacterium rhizogenes on five host plants. Indian Journal of Biotechnology 7:122-128

Ermayanti TM, Al-Hafiizh, Rahmawati S, Aryanti (2009) Transformasi Artemisia cina dan Artemisia annua dengan Agrobacterium rhizogenes. Journal of Applied and Industrial Biotechnology in Tropical Region 2 (2):1-5

Gelvin SB (2000) Agrobacterium and plant genes involved in T-DNA transfer and integration. Annual Review of Plant Physiology and Plant Molecular Biology 51(1): 223

$\mathrm{Hu}$ Z, Du M (2006) Hairy roots and its aplication in plant genetic engineering. Journal of Integrative Plant Biology 48(2): 121-127

Ikenaga T, Oyama T, Muranaka T (1995) Growth and steroidal saponin production in hairy root culture in Atropha belldona. Plant Cell Reports 14:413-417

Lee SY, Xu H, Kim YK, Park UP (2008) Rosmarinic acid producton in hairy root cultures of Agastache rugosa Kuntze. Journal of Microbiology and Biotechnology 24: 969-972

Manuhara YSW, Yachya A, Kristanti AN (2012) Effect of aeration density on biomass and saponin content of Talinum paniculatum Gaertn. hairy root in ballon type bubble bioreactor. Journal of Pharmacology and Biomedics Science 2(4):47-52

Murashige T, Skoog F (1962) A revised medium for rapid growth and bioassays with tobacco tissue culture. Physiologia Plantarum 15: 473

Nilsson O, Olsson O (1997) Getting to the root: the role of The Agrobacterium rhizogenes rol genes in the formation of hairy roots. Physiologia Plantarum 100: 463-473

Owens LD, Smigocki AC (1988) Transformation of soybean cells using mixed strains of Agrobacterium tumefaciens and phenolic compounds. Plant Physiology 88: 570-573

Pardal SJ, Wattimena GA, Aswidinnoor $\mathrm{H}$, Herman $\mathrm{M}$, Listanto E, Slamet (2004) Transfer gen proteinase inhibitor II pada kedelai melalui vektor Agrobacterium tumefasciens untuk ketahanan terhadap hama penggerek polong (Etiella zinckenella Tr.). Jurnal Bioteknologi Pertanian 9(1):20-28

Pawar PK, Maheswari VL (2004) Agrobacterium rhizogenes mediated hairy root induction in two medicinally important of family Solanaceae. Indian Journal of Biotechnology 3:414-417

Prajogo BEW, Dudy S, Mulja HS (2007) Analisis kadar gendarusin A pada tanaman budidaya Justicia gendarussa Burm. f.. Jurnal Farmasi Indonesia 3: $176-180$

Purnamaningsih R (2010) Introduksi gen DefH9-iaaM dan DefH9RI-iaaM ke dalam genom tanaman tomat menggunakan vektor Agrobacteriuum tumefasciens. Jurnal Agro Biogen 6(1): 18-25

Rahimi K, Haghbeen K, Marefatjo J, Jazii FR, Sheikhani R (2008) Successful production of hairy root of Valeriana 


\author{
sisymbriifolium \\ Agrobacterium \\ Biotechnology 7(2):200-204 \\ Saleh NM, Thuc LV (2009) \\ Assesssment of hairy roots \\ induction in Solenostemon \\ scutellarioides by different \\ strain of Agrobacterium \\ rhizogenes. African Journal of \\ Biotechnology 8(15):3519- \\ 3523 \\ Swain SS, Sahu L, Pal A, Barik DP, \\ Pradhan C, Chand PK (2012) \\ Hairy root cultures of butterfly \\ pea (Clitoria ternatea L.): \\ Agrobacterium X Plant factor \\ influencing transfomation. \\ Word Journal of Microbiology \\ and Biotechnology 28:729-739 \\ Syamkumar S, Sasikumar B (2007) \\ Molecular marker based \\ genetic diversity analysis of \\ curcuma species from India. \\ Scientia Horticulturae 112: \\ 235-241 \\ Toruan-Mathius NT, Reflini, Haris N, \\ Santoso J, Roswiem AP (2004) \\ Kultur akar rambut Cinchona \\ ledgeriana dan C. succirubra \\ dalam kultur in vitro. Menara \\ Perkebunan 72(2):72-87 \\ Toruan-Mathius NT, Siti-Chalimah, \\ Muhadiono, Aznam L, Haran S \\ (2007) Kultur akar rambut in \\ vitro serta pemanfaatan kultur \\ ganda untuk pertumbuhan dan \\ perkembangan endomikoriza \\ (Gigaspora sp. dan \\ Acaulospora sp.). Menara \\ Perkebunan 75(1): 20-31
}

Vazquez-Flota F, Moreno-Volenzuela $\mathrm{O}$, Miranda-Ham ML, LoyolaVorgas VM (1994) Catharantine and ajmalicine synthesis in Catharanthus roseus hairy root culture. Plant Cell Tissue, and Organ Culture 38: 273-279

Wahyuningtyas E (2011) Pengaruh konsentrasi dan lama waktu infeksi Agrobacterium rhizogenes strain 510 terhadap induksi akar eksplan daun gingseng jawa (Talinum paniculatum Gaertn.). Skripsi. Fakultas Sains dan Teknologi. Universitas Airlangga. Surabaya.

Wielanek M, Urbanek H (1999) Glucotropaeolin and myrosinase production in hairy root cultures of Tropaeolum majus. Plant Cell Tissue and Organ Culture 57: 39-45

Yonemitsu H, Shimosmura K, Satake M, Mochida S, Tanaka M, Endo T, Kaji A (1990) Lobeline production by hairy root culture of Lobelia inflata L. Plant Cell Report 9: 307-310

Zargar M, Farahani F, Nabavi T (2010) Hairy root production of transgenic Catharanthus roseus L. plants with Agrobacterium rhizogenes under in-vitro conditons. Journal of Medicinal Plants Research 4(21):2199-2203 